\title{
Defaunation affects the populations and diets of rodents in Neotropical rainforests
}

\author{
Mauro Galetti ${ }^{\text {a,* }}$, Roger Guevara ${ }^{\mathrm{b}}$, Carolina L. Neves ${ }^{\mathrm{a}}$, Raisa R. Rodarte ${ }^{\mathrm{a}}$, Ricardo S. Bovendorp ${ }^{\mathrm{a}}$, \\ Marcelo Moreira ${ }^{c}$, John B. Hopkins III ${ }^{\mathrm{d}, \mathrm{e}}$, Justin D. Yeakel ${ }^{\mathrm{f}}$ \\ ${ }^{a}$ Universidade Estadual Paulista (UNESP), Departamento de Ecologia, C.P. 199, Rio Claro, São Paulo 13506-900, Brazil \\ ${ }^{\mathrm{b}}$ Instituto de Ecología, A.C. Red de Biología Evolutiva, Carretera Antigua a Coatepec 351, El Haya, Xalapa, Veracruz 91070, Mexico

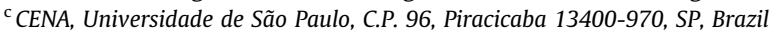 \\ ${ }^{\mathrm{d}}$ Department of Ecology and Evolutionary Biology, University of California Santa Cruz, Santa Cruz, CA, USA \\ ${ }^{\mathrm{e}}$ School of Life Sciences, Peking University, Beijing, China \\ ${ }^{\mathrm{f}}$ Santa Fe Institute, Santa Fe, NM, USA
}

\section{A R T I C L E I N F O}

\section{Article history:}

Received 10 January 2015

Received in revised form 23 April 2015

Accepted 28 April 2015

Available online 1 June 2015

\section{Keywords:}

Akodon

Defaunation

Oligoryzomys

Zoonosis

Diet overlap

Trophic cascade

\begin{abstract}
A B S T R A C T
Most tropical rainforests have been defaunated of large-bodied mammals and the cascading effects of such extirpations have been poorly studied, particularly on other animals. We used a natural experiment in the Brazilian Atlantic rainforest to investigate the ecological responses of rodents to the functional extinction of a dominant terrestrial mammal, the white-lipped peccary (Tayassu pecari). We detected a $45 \%$ increase in the abundance and a decrease in diversity of rodents in defaunated forests. Two of these species (Akodon montensis and Oligoryzomys nigripes) are important hosts of Hantavirus, a lethal virus for humans. Stable isotope ratios $\left(\delta^{13} \mathrm{C}\right.$ and $\left.\delta^{15} \mathrm{~N}\right)$ derived from the hair of rodents and peccaries and their food resources indicate that at least two rodent species shifted to a diet more similar to peccaries in the defaunated forest. Because most tropical rainforests are facing dramatic extirpation of large mammals, we can expect changes in the composition and structure of small mammal communities with potential consequences for human health even in non-fragmented landscapes.
\end{abstract}

(c) 2015 Elsevier Ltd. All rights reserved.

\section{Introduction}

Understanding the role of species interactions in structuring animal communities, particularly competition and predation, has been a fundamental challenge facing naturalists and ecologists for decades (Brown and Davidson, 1977; Elton, 1927). This topic has received particular attention in human-modified ecosystems where the local extinction of apex consumers (predators or herbivores) may trigger trophic cascades and change the nature or strength of inter-specific interactions (Dirzo et al., 2014; Estes et al., 2011; Ripple et al., 2014).

In most tropical regions, large forest-dwelling mammals, particularly ungulates, have become locally or functionally extinct due to habitat loss, fragmentation, and poaching (Jorge et al., 2013; Peres and Palacios, 2007). The effects of such losses are many-fold because these large mammals regulate interspecific trophic interactions via resource competition or habitat modification (Palmer et al., 2008; Pringle, 2008). For instance, the population growth

\footnotetext{
* Corresponding author.

E-mail address: mgaletti@rc.unesp.br (M. Galetti).
}

of small rodents occurs in response to the exclusion of large mammals in African savannas (Keesing, 1998; Maclean et al., 2011; McCauley et al., 2006) and temperate forests (Parsons et al., 2013). However, the mechanisms that explain the changes in rodent abundance are still debated. Two major hypotheses try to explain the mechanism on how large ungulates control the abundance of small mammals. The "relaxed competition hypothesis" is based on the assumption of considerable diet overlap between rodents and ungulates, i.e. once ungulates are extirpated, rodent species with similar diet increase in abundance (Keesing, 2000). The "habitat interference hypothesis" suggests that large herbivores change either by browsing or trampling the vegetation structure making small mammals more vulnerable to predation risk (Keesing, 1998).

These hypotheses have been tested in relatively simple communities, where the diversity of rodents is low (Keesing, 2000). In Neotropical rainforests, several forest-dwelling ungulates such as deer (Mazama spp.), collared and white-lipped peccaries (Pecari tajacu and Tayassu pecari, respectively) can compete with small mammals for fruits and seeds (Beck, 2006; Gayot et al., 2004). In pristine non-hunted forests, white-lipped peccaries are the 
dominant terrestrial mammal in terms of density and biomass (Peres, 1996). White-lipped peccaries weigh on average $32 \mathrm{~kg}$ and forage in large, cohesive herds of up to 100-300 animals (Kiltie and Terborgh, 1983). This species has profound density dependent effects on the survival of several plant species because they trample and plow the forest understory, preying upon seeds, seedlings, and saplings (Silman et al., 2003). In addition, white-lipped peccaries have been considered ecosystem engineers because plowing the soil and litter, they also create and maintain wallows that are used by many other species as breeding and foraging habitats such as amphibians and reptiles (Beck et al., 2010; Reider et al., 2013). Nowadays, peccaries are locally extinct in most of their former range (Altrichter et al., 2012; Jorge et al., 2013).

In the Atlantic rainforests of Brazil most large mammal populations rely on large continuous forests in Serra do Mar, a 1 million ha forest that lies along the coast of Brazil (Galetti et al., 2009). Illegal hunting has recently driven several populations of large-bodied mammals to local extinction, creating a mosaic of different levels of defaunation in contiguous forests (Cullen Jr. et al., 2004; Keuroghlian et al., 2012; Jorge et al., 2013). The extirpation of white-lipped peccaries from tropical forests thus offers an opportunity to test for the presence of indirect effects in defaunated tropical landscapes.

Here, we tested the hypothesis that the extirpation of white-lipped peccaries would increase the abundance of small mammals (Keesing, 1998). We conducted our natural experiment by measuring the abundance and diversity of rodents in a site where peccaries currently occur and a site where peccaries are functionally extinct (hereafter, peccary vs. non-peccary sites). Our prediction is that in the non-peccary site (1) the composition of rodents will be dominated by few species, leading to impoverished species richness and (2) the species with similar diet with peccaries would have higher abundance, suggesting a competition release. We then calculated dietary overlap between white-lipped peccaries and small mammals by analyzing ratios of naturally occurring carbon and nitrogen stable isotopes (expressed as $\delta^{13} \mathrm{C}$ and $\delta^{15} \mathrm{~N}$ values, respectively) in the hair of both peccary and rodent consumers. We expect greater dietary overlap between peccaries and rodents that increase their abundance in the absence of peccaries.

\section{Materials and methods}

\subsection{Study sites}

We conducted the study by sampling rodents in a contiguous Atlantic rainforests of south-eastern Brazil. We chose two sites with contrasting biomass of large mammals: Itamambuca (hereafter peccary-site) $\left(23^{\circ} 19^{\prime} \mathrm{S}, 45^{\circ} 5^{\prime} \mathrm{W}\right)$ and Vargem Grande (non-peccary site) $\left(23^{\circ} 26^{\prime} \mathrm{S}, 45^{\circ} 14^{\prime} \mathrm{W}\right.$; Fig. S1, Supplemental Material) both located in the Serra do Mar State Park. The two sites are $15 \mathrm{~km}$ apart and are similar in altitude and plant composition (Joly et al., 2012), but differ in the biomass of large mammals, particularly white-lipped peccaries, T. pecari (Rocha-Mendes et al., 2015). The non-defaunated site is better protected against illegal hunting and therefore has a relative biomass of mid and large mammals 4-fold higher than defaunated sites (Rocha-Mendes et al., 2015; Efford and Fewster, 2013; R Development Core Team, 2014). The white-lipped peccary (T. pecari) represents $41 \%$ of the crude biomass in the non-defaunated site and it is functionally extinct in the defaunated site. Both sites have suitable habitats for peccaries (Norris et al., 2011), but are divided by a highway (BR 383) with heavy traffic that serves as a movement barrier to most animals in both sites.

\subsection{Diversity and population abundance of rodents}

In each site we arranged three independent 0.6 ha grids $(60 \times 100 \mathrm{~m}$ each $)$ of live-traps and six transects of pitfall-traps to capture small mammals (see Supplemental material for details). Rodents were captured-marked-recaptured using two standard types of traps: live-traps (Sherman and Tomahawk-live trap) and pitfall-traps. Trapping sessions were carried out bimonthly comprising five consecutive nights at each site during one year (November 2008 to September 2009). Overall our sampling effort at each site consisted of 3420 trap-nights, 2700 for live-traps and 720 for pitfall-traps site. To minimize pseudo-replication at the grid level we spaced all grids and pit-falls transects in each site at least $100 \mathrm{~m}$ from each other.

We use the number of individuals by 100-trap-nights to calculate the abundance and spatially explicit capture-recapture (SECR) models (Efford and Fewster, 2013) in R to calculate the density for rodents (R Development Core Team, 2014). The data of captures of live and pitfall traps were analyzed separately. Because we did not have enough recaptures, we then use relative abundance. Changes in abundance were estimated as the quotient of the difference in abundance between sites divided by the overall abundance in both sites, and tested by Monte Carlo resampling (see Supplementary materials).

\subsection{Stable isotope analysis}

We used stable isotope values $\left(\delta^{13} \mathrm{C}, \delta^{15} \mathrm{~N}\right)$ derived from the hair of consumers to estimate the similarity in diets between consumers and peccaries. In this case, a geometric approach (Newsome et al., 2012) to estimate similarity in diets is more appropriate than the use of stable isotope mixing models (Phillips, 2001; Hopkins and Ferguson, 2012; Parnell et al., 2013; Phillips et al., 2014). First, we are not confident that we sampled all the foods consumers eat. Using potential resources, instead of known resources, to build an isotopic mixing space (the area or volume contained within the lines connecting dietary sources in a multivariate plot of isotope values) will likely bias dietary estimates. Second, and more importantly, discrimination factors (small offsets of isotope values between dietary sources and animal tissues due to metabolic and digestive processes) for hair are unknown for the major foods sources in this study, which include berries, seeds, and fungi. Applying inappropriate discrimination factors can severely bias dietary estimates calculated by stable isotope mixing models.

We estimated dietary similarity between peccaries and rodents by analyzing the $\delta^{13} \mathrm{C}$ and $\delta^{15} \mathrm{~N}$ values derived from their hair. We collected hair from peccaries and rodents during the same time period using a series of barbed wire hair traps (Biondo et al., 2010) and live- and pitfall-traps, respectively. Hair traps consisted of approximately $16 \mathrm{~m}^{2}$ of barbed wire wrapped around trees, baited with corn. We used one strand of wire positioned at a height of $40 \mathrm{~cm}$ above the ground, which is approximately $15 \mathrm{~cm}$ lower than the mean height of an adult white-lipped peccary. We deployed the hair traps in places frequented by white-lipped peccaries such as foraging trails and resting sites. We avoid collecting hairs from the same peccary by genotyping half of the hair and using the other half for isotopic analyses.

Carbon and nitrogen stable isotope ratios were measured by continuous flow isotope ratio mass spectrometry with a Thermo Delta Plus mass spectrometer (Bremen, Germany) coupled to a Carlo Erba CHN 1110 elemental analyzer (Milan, Italy). Results from stable isotope analysis are expressed in $\delta$ (delta) notation as parts per thousand or per mil (\%o) and reported as:

$\delta^{j} X=\frac{\left({ }^{j} X /{ }^{i} X\right)_{\text {sample }}}{\left({ }^{j} X /{ }^{i} X\right)_{\text {standard }}}-1$, 
where ${ }^{j} X$ is the heavier isotope $\left({ }^{13} \mathrm{C}\right.$ or $\left.{ }^{15} \mathrm{~N}\right)$, and ${ }^{j} X$ is the lighter isotope $\left({ }^{12} \mathrm{C}\right.$ or $\left.{ }^{14} \mathrm{~N}\right)$ in the analytical sample and international measurement standard (Pee Dee Belemnite and atmospheric $\mathrm{N}_{2}$ for carbon and nitrogen, respectfully). In general, the $\delta^{15} \mathrm{~N}$ values of consumer tissues increase with trophic level, and $\delta^{13} \mathrm{C}$ values indicate the photosynthetic pathway of the plants ingested by consumers (Newsome et al., 2007).

We used a Shapiro-Wilk test to determine if stable isotope values for food groups and consumer hair were normally distributed. We then used a Student's t-test (if normally distributed) or MannWhitney $U$ test (if non-normally distributed) to compare isotope values of foods within sites and foods and consumers between sites.

We estimated dietary overlap from the isotopic similarity between peccaries and each small mammal population (i) within each site. We calculated the means and covariance matrices that describe the multivariate normal isotopic distributions $\left(\delta^{13} \mathrm{C}\right.$ vs. $\delta^{15} \mathrm{~N}$ values) for peccaries, as well as for small mammal species in peccary and non-peccary sites. The area of overlap between two standard ellipses was calculated using the $\mathrm{R}$ package SIBER (Jackson et al., 2011). To emphasize the difference between each species $i$ and peccaries, we multiplied the covariance matrix of the peccary isotopic distribution by a factor of 3 , as visualized by the peccary standard ellipse in Fig. 3A. The Similarity Index is thus calculated as

Similarity Index ${ }_{i}=\frac{w_{\text {pecc }, i}(\text { non }- \text { peccary })}{w_{\text {pec }, i}(\text { peccary })}$,

where values greater than unity imply that small mammals adopt more peccary-like diets (defined by a consumer with similar isotope values as peccaries) when peccaries are absent, and values less than unity imply that small mammals adopt peccary-like diets when peccaries are present.

\section{Results}

\subsection{Diversity and population abundance of rodents}

We trapped 620 individuals and recorded 19 species of small mammals, which consisted of 13 rodent and 6 marsupial species (Table 1). Here we will present data and discuss only for rodents because marsupial populations did not differ between sites $(F=3.16 ;$ d.f. $=1,5 ; P=0.1355)$. We detected more rodent species at the peccary site than the non-peccary site only when we analyzed data of pitfall traps (Fig. 1, and Table S1, Supplemental Material), supporting prediction 1 . All but one of the 19 species were captured in the peccary site, while 15 species and $45 \%$ more individuals were caught in the non-peccary site (Table 1).

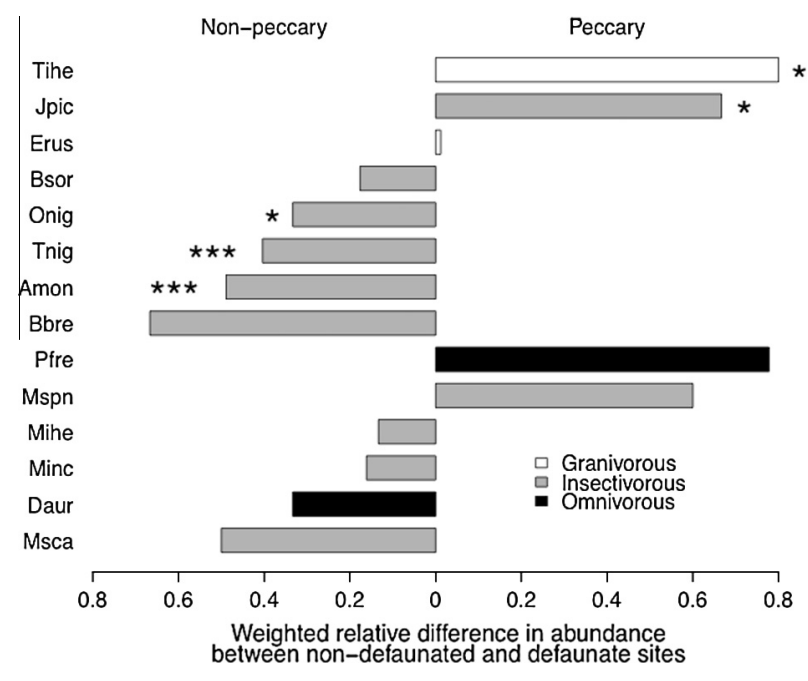

Fig. 1. Weighted relative change in abundance [(peccary - non-peccary)/(peccary + non-peccary)] of small mammals in two site of the Atlantic Rain forest ( where Tihe $=$ Trinomys ihenringi, Jpic $=$ Juliomys pictipes, Erus = Euryoryzomys russatus, Bsor = Brucepattersonius soricinus, Onig = Oligoryzomys nigripes, Tnig $=$ Thaptomys nigrita,$\quad$ Bbre $=$ Blarinomys breviceps, Pfre $=$ Phylander frenata , Mspn $=$ Monodelphis sp., Mihe $=$ Monodelphis iheringi, Minc $=$ Monodelphis incanus, Daur = Didelphis aurita, Msca = Monodelphis scalops).

Rodent abundance for every 100-trap-nights was on average $47 \%$ higher in the non-peccary site $(F=8.87$; d.f. $=1,5$; $P=0.0309$ ) compared with the peccary site. At the species level, the Monte Carlo randomization test showed that Akodon montensis $(P<0.001)$, Thaptomys nigrita $(P<0.001)$ and Oligoryzomys nigripes $(P=0.024)$ were significantly more abundant in the non-peccary site while Trinomys iheringi $(P=0.016)$ and Juliomys pictipes $(P=0.046)$ were significantly more abundant in the peccary site (Fig. 2). One species (Euryzomys russatus) did not change its abundance in either site. Individual-based rarefaction curves showed that in the peccary site, despite having an overall lower abundance of rodents, the community of small and medium sized mammals had higher diversity because species accumulated more quickly as sampling effort increased (Fig. S2, Supplemental material).

The 19 species recorded in this study represent four main trophic groups where insectivores and granivores were the best-represented in both sites, where the presence of omnivores and folivores were rare. In the peccary site, insectivorous rodents were ca. two times more abundant than granivores, while in the non-peccary site insectivores were ca. four times more abundant than granivores (non-peccary site: $t=2.13$, d.f. $=198, P<0.0001$; peccary site: $t=3.19$, d.f. $=198, P<0.0001$ ). The difference in the ratios of insectivores to granivores in the peccary and

Table 1

Isotope values (\%) and number of individuals captured of small mammals at sites with and without peccaries in the Brazilian Atlantic rainforests.

\begin{tabular}{|c|c|c|c|c|c|c|c|c|c|}
\hline \multirow[t]{2}{*}{ Species } & \multirow[t]{2}{*}{ Mean Body Mass (g) } & \multirow[t]{2}{*}{ Locomotion } & \multirow[t]{2}{*}{ Diet } & \multicolumn{2}{|c|}{ Without peccaries } & \multicolumn{2}{|c|}{ With peccaries } & \multicolumn{2}{|l|}{ \# captured } \\
\hline & & & & $\delta^{15} \mathrm{~N}$ & $\delta^{13} \mathrm{C}$ & $\delta^{15} \mathrm{~N}$ & $\delta^{13} \mathrm{C}$ & Without peccaries & With peccaries \\
\hline Akodon montensis & 32 & Terrestrial & Insectivore & +6.7 & -23.8 & +8.2 & -24.4 & 67 & 23 \\
\hline Blarinomys breviceps & 22 & Semifossorial & Insectivore & +10.0 & -23.6 & NA & NA & 5 & 1 \\
\hline Brucepattersonius soricinus & 33 & Semifossorial & Insectivore & +10.3 & -22.835 & +9.8 & -23.2 & 10 & 7 \\
\hline Calomys tener & 10 & Terrestrial & Granivore & NA & NA & NA & NA & 1 & 0 \\
\hline Euryoryzomys russatus & 75 & Terrestrial & Granivore & +4.943 & -25.0 & +5.8 & -25.1 & 84 & 86 \\
\hline Juliomys pictipes & 18 & Scansorial & Granivore & NA & $\mathrm{NA}$ & NA & NA & 2 & 10 \\
\hline Nectomys squamipes & 196 & Terrestrial & Granivore & NA & NA & NA & NA & 0 & 1 \\
\hline Oecomys spp. & 54 & Arboreal & Folivore & NA & NA & NA & NA & 0 & 2 \\
\hline Oligoryzomys nigripes & 16 & Scansorial & Insectivore & +5.8 & -17.5 & +6.7 & -14.8 & 42 & 21 \\
\hline Rhipidomys mastacalis & 51 & Arboreal & Granivore & NA & NA & NA & NA & 0 & 1 \\
\hline Sooretamys angouya & 138 & Terrestrial & Granivore & NA & NA & +3.0 & -25.3 & 0 & 4 \\
\hline Thaptomys nigrita & 21 & Terrestrial & Insectivore & +3.1 & -8.9 & +7.8 & -24.0 & 106 & 45 \\
\hline Trinomys iheringi & 210 & Terrestrial & Granivore & +5.1 & -26.5 & +4.8 & -24.4 & 1 & 9 \\
\hline
\end{tabular}




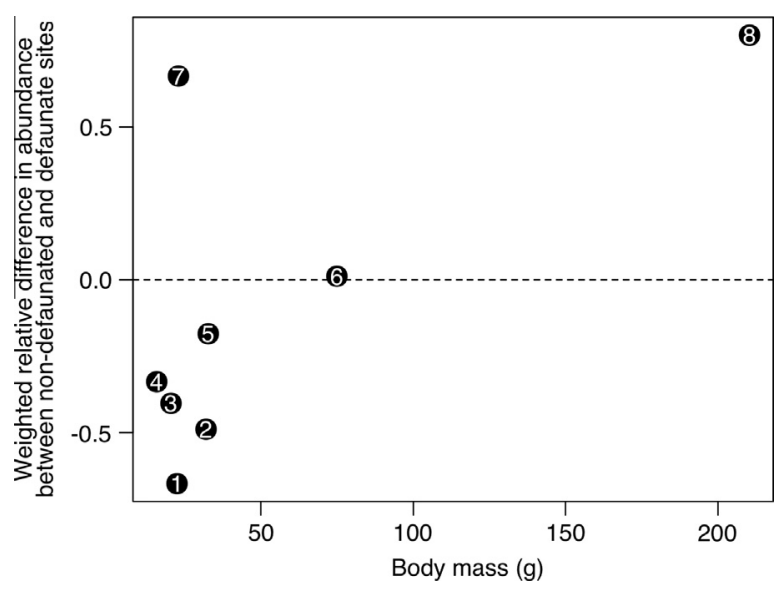

Fig. 2. Differences in abundance of rodents between sites where peccaries are present and absent and rodent body mass $(1=$ Blarinomys breviceps, $2=$ Akodon montensis, 3 =Thaptomys nigrita, 4 = Oligoryzomys nigripes, $5=$ Brucepattersonius soricinus, 6 = Euryoryzomys russatus, 7 = Juliomys pictipes, 8 = Trinomys iheringi).

non-peccary sites was driven solely by the higher abundance of insectivores in the non-peccary site compared with the peccary site $(t=2.62$, d.f. $=5, P=0.0472)$, since the abundance of granivores did not vary significantly between the two sites $(t=1.25$, d.f. $=5$, $P=0.2583$ ).

For rodents in the peccary site the most abundant functional group was of terrestrial habit and was over 19 times more abundant than arboreal species $(t=5.8$, d.f. $=30, P<0.0001)$, over four times more abundant than semifossorial species $(t=4.7$, d.f. $=30$, $P<0.0001$ ), and over three times more abundant than scansorial species $(t=4.1$, d.f. $=30, P=0.0001)$. In the non-peccary site, the terrestrial habit was also the best-represented functional group and was over 67 times more abundant than arboreal species $(t=4.5$, d.f. $=30, P<0.0001)$, ca. three times more abundant than semifosorial species ( $t=2.8$, d.f. $=30, P=0.0048)$, and ca. five times more abundant than scansorial species $(t=3.5$, d.f. $=30$, $P=0.0005)$. Moreover, the abundance of semifossorial rodents in the non-peccary sites was over 3.5 times that of the peccary site $(t=3.0$, d.f. $=5, P=0.0288)$, and the abundance of terrestrial rodents in the non-peccary site was over two fold that of the peccary site $(t=2.3$, d.f. $=5, P=0.0349)$.

\subsection{Stable isotope analysis of foods and consumers}

We found no differences in isotope values of consumer foods (insects, fungi, and seeds) between sites except for fruits $\left(\delta^{13} \mathrm{C}\right.$ : $t=4.6346, \quad \mathrm{df}=15.994, \quad P<0.005 ; \quad \delta^{15} \mathrm{~N}: t=2.9787, \quad \mathrm{df}=15.993$, $P=0.009$, Table 2 ). We also found that isotope values for seeds and fruits were similar $\left(\delta^{13} \mathrm{C}: \quad W=35, \quad \mathrm{P}=0.491 ; \quad \delta^{15} \mathrm{~N}\right.$ : $t=-1.6705, \mathrm{df}=7.721, P=0.1347)$ and depleted in ${ }^{13} \mathrm{C}$ and ${ }^{15} \mathrm{~N}$ relative to insects and fungi (Table 2). Lastly, we found that isotope values for seeds and insects were significantly different $\left(\delta^{13} \mathrm{C}\right.$ : $\left.W=144, \quad P=0.02199 ; \delta^{15} \mathrm{~N}: t=2.3216, \mathrm{df}=8.417, \quad P=0.04726\right)$. Isotopic differences between fruit/seed and insect/fungi resource groups (Fig. 3) allowed us to test the prediction that isotope values for some small mammal populations in the non-peccary site would be more similar to those of peccaries, suggesting diets with greater contributions from seeds and fruits.

Table 2

Isotopic values of the main food sources of rodents and peccaries in the Atlantic forest, Brazil.

\begin{tabular}{llllll}
\hline \multirow{2}{*}{ Resource } & \multicolumn{2}{l}{ Without peccaries } & & \multicolumn{2}{l}{ With peccaries } \\
\cline { 2 - 3 } \cline { 5 - 6 } & $\delta^{13} \mathrm{C}($ mean $\pm \mathrm{SD})$ & $\delta^{15} \mathrm{~N}$ & & $\delta^{13} \mathrm{C}$ & $\delta^{15} \mathrm{~N}$ \\
\hline Fruit & $-27.4 \pm 0.5$ & $+2.6 \pm 0.4$ & & $-27.4 \pm 0.5$ & $+2.6 \pm 0.4$ \\
Seeds & $-29.7 \pm 2.8$ & $+1.8 \pm 2.1$ & & $-29.0 \pm 3.1$ & $+3.1 \pm 6.6$ \\
Insects & $-27.5 \pm 3.0$ & $+2.3 \pm 6.5$ & & $-26.5 \pm 2.7$ & $+5.2 \pm 2.7$ \\
Fungi & $-24.5 \pm 1.5$ & $+6.4 \pm 4.5$ & & $-25.4 \pm 1.6$ & $+7.9 \pm 3.6$ \\
\hline
\end{tabular}
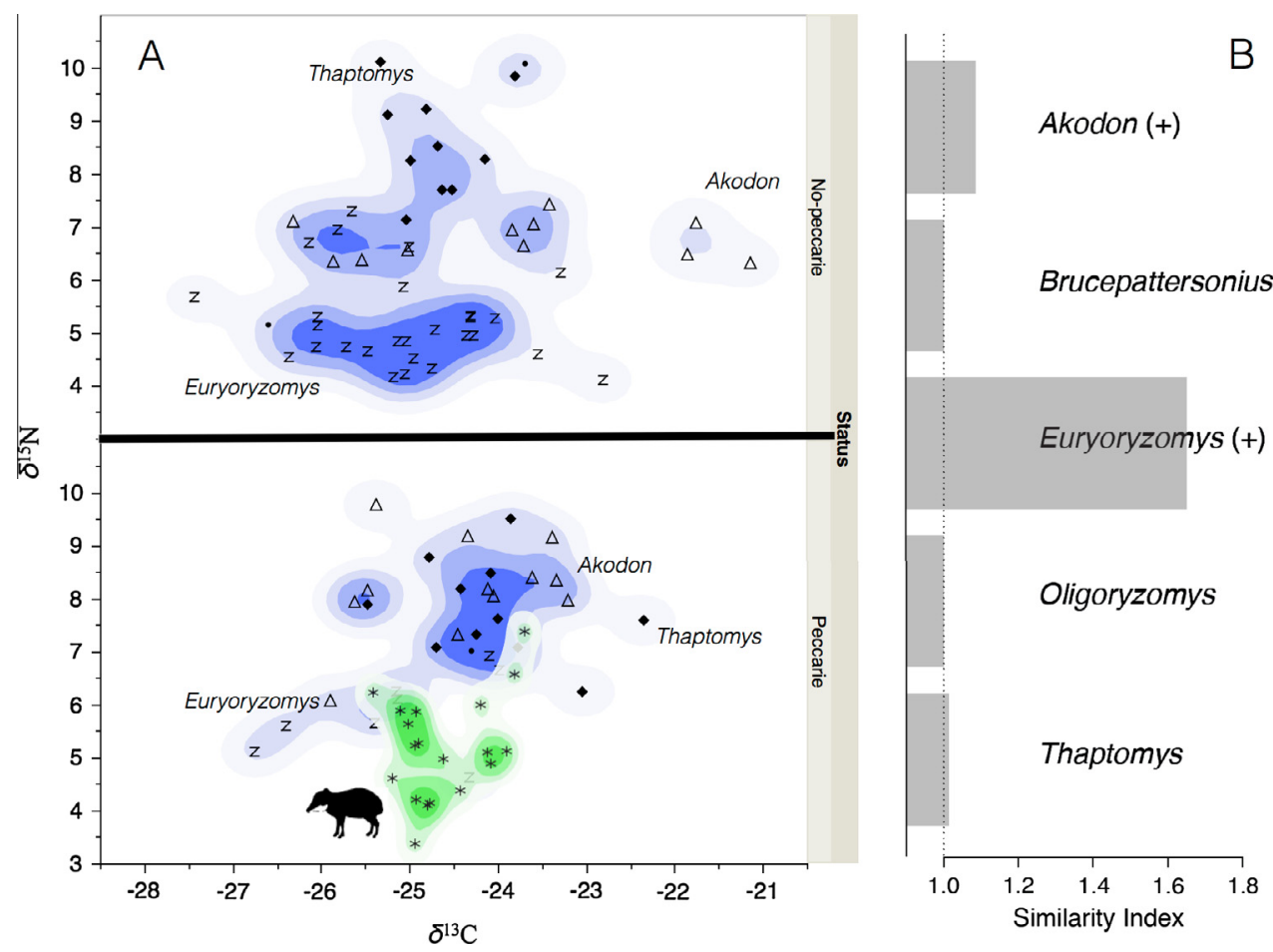

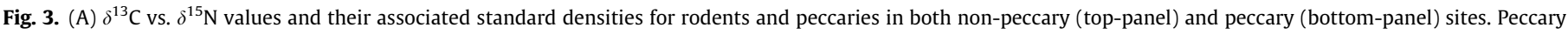

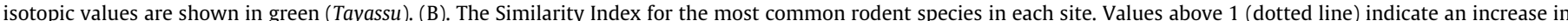

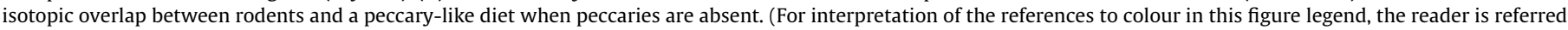
to the web version of this article.) 


\subsection{Isotopic overlap of consumers}

The mean $\delta^{13} \mathrm{C}$ (non-peccary $=-24.2 \pm 2.7$, peccary $=$ $-23.7 \pm 2.8$ ) and $\delta^{15} \mathrm{~N}$ (non-peccary $=6.9 \pm 1.8$, peccary $=7.5 \pm 1.8$ ) isotope values of small mammals were lower $\left(\delta^{13} \mathrm{C}: W=1264\right.$, $\left.P=0.059 ; \delta^{15} \mathrm{~N}: W=1226.5, P=0.113\right)$ in the non-peccary site. We found that changes in the mean $\delta^{13} \mathrm{C}$ and $\delta^{15} \mathrm{~N}$ values of small mammals were idiosyncratic with respect to peccary presence/absence at the species level, and that these differences were not correlated with changes in abundance. Although rodents show an increase in abundance when peccaries are absent, the mean $\delta^{13} \mathrm{C}$ values for each species change little between sites. In contrast, the mean $\delta^{15} \mathrm{~N}$ values varied more widely between sites across species. For instance, Brucepattersonius and Thaptomys have lower mean $\delta^{15} \mathrm{~N}$ values when peccaries are present, while Akodon, Euryoryzomys, and Oligoryzomys tend to have higher mean $\delta^{15} \mathrm{~N}$ values when peccaries are present (Fig. 3A).

The potential decrease in $\delta^{13} \mathrm{C}$ and $\delta^{15} \mathrm{~N}$ values in consumer hair at the non-peccary site suggests that some rodent species may adopt more peccary-like diets consisting of fruits and seeds in the absence of competition (peccary-like diets are represented in green in Fig. 3A). When peccaries are absent, the overlap in the diet characterizing some rodent isotopic distributions (Akodon and Euryoryzomys) increases relative to that of peccary-like diets, such that the Similarity Index based on isotopic overlap (see Section 2) becomes greater than unity. Ecologically, an increase in overlap corresponds to a dietary shift toward a peccary-like diet when peccaries are absent, or alternatively, a shift away from a peccary-like diet when peccaries are present. This change in the isotopic niche-space may result from either direct or indirect competitive exclusion. In contrast, the overlap between the other rodent species and peccaries tends to remain unchanged or decrease when peccaries are absent, such that the Similarity Index $\leqslant 1$ (Fig. 3A).

\section{Discussion}

Results from our study support the hypothesis that the local extinction of a dominant ungulate has an effect on the abundance and diversity of small mammals in species-rich communities such as tropical rainforests (Wright, 2003); a phenomenon already observed in temperate woodlands (Buesching et al., 2011) and African savannas (McCauley et al., 2006). In particular, we found that the overall diversity of small mammals decreased in the non-peccary site and the abundance of rodents increased twofold, a similar magnitude to the effect of large mammals on rodents in African savanna (McCauley et al., 2006). Three of the four most common rodent species (A. montensis, $O$. nigripes, $T$. nigrita), which represent $69 \%$ of the individuals captured in peccary site, increase their abundance from 2 to 3 -fold when peccaries are absent, while the population of $E$. russatus remains similar in both areas. Two of these rodents (A. montensis and 0 . nigripes) reach $67 \%$ of all individuals trapped, while $T$. nigrita became extremely rare and $E$. russatus are locally extinct in small forest fragments near the study site (Paise, 2010). Because we fail to detect other differences between sites that could affect the abundance of small mammals (such as predation risk, microhabitat characteristics and primary productivity (see Supplemental Material for alternative hypotheses), our results suggest that white-lipped peccaries structure the composition of small rodents keeping the abundance of dominant species low.

In addition, our results support both the "relaxed competition hypothesis" and the "habitat interference hypothesis" (Foster et al., 2014) via multiple pathways. Our analysis of dietary overlap indicates that white-lipped peccaries compete with granivorous rodents $E$. russatus and $A$. montensis. Isotope values for the large-bodied rodent, E. russatus, slightly overlap with peccaries when they co-occur; however, when peccaries are extirpated, $E$. russatus shifted to a more peccary-like diet, consisting of seeds and fruits (suggesting relaxed competition occurred). Thus, E. russatus is not demographically affected by the presence of peccaries, but were likely forced to feed on more difficult to consume foods such as insects or nutrient-deficient foods, leading to lower body condition and increasing competition with small insectivorous rodents. We believe that because E. russatus is from 2.5 to 4.5 times bigger than the insectivorous rodents, they can over-compete or displace smaller rodents. Long-term experiments in desert ecosystems have found that the density of small granivorous rodents increases 3.5 times when large rodents are excluded (Munger and Brown, 1981). A. montensis, which is twice smaller than E. russatus, also shifted to a more peccary-like diet in the defaunated forest, but has lower abundance is the peccary-site.

In addition, the foraging behavior of white-lipped peccaries in plowing soil and litterfall may indirectly interfere with the habitat quality or structure of the fossorial rodents, such as T. nigrita, $B$. soricinus and $B$. breviceps, but were not quantified in this study. One species ( $O$. nigripes) is particularly intriguing because they have low diet overlap with peccaries, but their population is heavily affected in peccary-site.

In summary, the results of our natural experiment thus indicate that large herbivores can serve to maintain a higher diversity of rodent species, suppressing the populations of dominant rodents via resource competition with granivores and interfering in the habitat of fossorial insectivores. Moreover, these findings have important implications for human-health because two of the three rodent species that increase their abundance in defaunated forests (A. montensis and O. nigripes) are important hosts of Hantavirus, a lethal and emerging zoonosis for humans (Suzuki et al., 2004) that has been usually related to the decline of rodent diversity in forest fragments (Suzán et al., 2009). Because white-lipped peccaries have been extirpated from most of their former distribution in the Neotropics (Altrichter et al., 2012), and are already locally extinct in most of the Atlantic forest remnants (Jorge et al., 2013), defaunated non-fragmented forests may in turn contribute to an increase in the population of Hantavirus hosts and ultimately trigger the emergence and spread of lethal diseases in human populations (Donalisio and Peterson, 2011; Jones et al., 2013).

\section{Acknowledgements}

Fieldwork was carried out with help from L.M. Silva, E.C. Silva, R. Brandolim, L. Galbiati, M. Madeira, and S. Nazareth. E. Becker, T. Carlo and two anonymous reviewers for comments on the manuscript. We thank Fundação Florestal/SP (particularly João Paulo Villani) for permitted and supported the fieldwork at Parque Estadual da Serra do Mar. Gabriela Schmaedecke allow us to use her data on camera trapping. We thank Fundação de Amparo 'a Pesquisa do Estado de São Paulo - FAPESP (Proc. 2007/03392-6 and 2014/01986-0) for financial support. M. Galetti receives a CNPq fellowship. C.L. Neves and RR received a CNPq fellowship and RSB receives a post-doctoral fellowship from FAPESP. Collecting permits was provided by Instituto Brasileiro do Meio Ambiente e dos Recursos Naturais Renováveis (IBAMA, \#14428-2).

\section{Appendix A. Supplementary material}

Supplementary data associated with this article can be found, in the online version, at http://dx.doi.org/10.1016/j.biocon.2015.04. 032 . 


\section{References}

Altrichter, M., Taber, A., Beck, H., Reyna-Hurtado, R., Lizarraga, L., Keuroghlian, A. Sanderson, E.W., 2012. Range-wide declines of a key Neotropical ecosystem architect, the Near Threatened white-lipped peccary Tayassu pecari. Oryx 46 87-98.

Beck, H., 2006. A review of peccary-palm interactions and their ecological ramifications across the Neotropics. J. Mammal. 87, 519-530.

Beck, H., Thebpanya, P., Filiaggi, M., 2010. Do Neotropical peccary species (Tayassuidae) function as ecosystem engineers for anurans? J. Trop. Ecol. 26, 407-414.

Biondo, C., Gonçalves, H.S., Bernardo, C., Galetti, M., 2010. Hair trap efficacy to sample white-lipped peccaries (Tayassu pecari). Suiform Soundings 10, 24-27.

Brown, J.H., Davidson, D.W., 1977. Competition between seed-eating rodents and ants in desert ecosystems. Science 196, 880-882.

Buesching, C.D., Newman, C., Jones, J.T., Macdonald, D.W., 2011. Testing the effects of deer grazing on two woodland rodents, bankvoles and woodmice. Basic Appl. Ecol. 12, 207-214.

Cullen Jr., L., Bodmer, R.E., Valladares-Padua, C., Ballou, J.D., 2004. Mammalian densities and species extinctions in Atlantic forest fragments. In: Silvius, K.M., Bodmer, R.E., Fragoso, J.M. (Eds.), People in Nature: Wildlife Conservation in South and Central America. Columbia University Press, New York, pp. 211-226.

Dirzo, R., Young, H.S., Galetti, M., Ceballos, G., Isaac, N.J.B., Collen, B., 2014. Defaunation in the Anthropocene. Science 345, 401-406.

Donalisio, M.R., Peterson, A.T., 2011. Environmental factors affecting transmission risk for hantaviruses in forested portions of southern Brazil. Acta Tropica 119, $125-130$.

Efford, M.G., Fewster, R.M., 2013. Estimating population size by spatially explicit capture-recapture. Oikos 122, 918-928.

Elton, C.S., 1927. Animal Ecology. The University of Chicago Press, London.

Estes, J.A., Terborgh, J., Brashares, J.S., Power, M.E., Berger, J., Bond, W.J., Carpenter, S.R., Essington, T.E., Holt, R.D., Jackson, J.B.C., Marquis, R.J., Oksanen, L., Oksanen, T., Paine, R.T., Pikitch, E.K., Ripple, W.J., Sandin, S.A., Scheffer, M., Schoener, T.W., Shurin, J.B., Sinclair, A.R.E., Soule, M.E., Virtanen, R., Wardle, D.A., 2011. Trophic downgrading of planet earth. Science 333, 301-306.

Foster, C.N., Barton, P.S., Lindenmayer, D.B., du Toit, J., 2014. Effects of large native herbivores on other animals. J. Appl. Ecol. 51, 929-938.

Galetti, M., Giacomini, H.C., Bueno, R.S., Bernardo, C.S.S., Marques, R.M., Bovendorp, R.S., Steffler, C.E., Rubim, P., Gobbo, S.K., Donatti, C.I., Begotti, R.A., Meirelles, F., Nobre, R.d.A., Chiarello, A.G., Peres, C.A., 2009. Priority areas for the conservation of Atlantic forest large mammals. Biol. Conserv. 142, 12291241.

Gayot, M., Henry, O., Dubost, G., Sabatier, D., 2004. Comparative diet of the two forest cervids of the genus Mazama in French Guiana. J. Trop. Ecol. 20, 31-43.

Hopkins, J.B., Ferguson, J.M., 2012. Estimating the diets of animals using stable isotopes and a comprehensive Bayesian mixing model. PLoS ONE 7, e28478. http://dx.doi.org/10.1371/journal.pone.0028478.

Jackson, A.L., Inger, R., Parnell, A.C., Bearhop, S., 2011. Comparing isotopic niche widths among and within communities: SIBER - Stable Isotope Bayesian Ellipses in R. J. Animal Ecol. 80 (3), 595-602. http://dx.doi.org/10.1111/j.13652656.2011.01806.x.

Joly, C.A., Assis, M.A., Bernacci, L.C., Tamashiro, J.Y., Campos, M.C.R., Gomes, J.A.M.A Lacerda, M.S., Santos, F.A.M., Pedroni, F., Pereira, L.S., Padgurschi, M.C.G., Prata E.M.B., Ramos, E., Torres, R.B., Rochelle, A., Martins, F.R., Alves, L.F., Vieira, S.A., Martinelli, L.A., Camargo, P.B., Aidar, M.P.M., Eisenlohr, P.V., Simoes, E., Villani, J.P., Belinell, R., 2012. Floristic and phytosociology in permanent plots of the Atlantic Rainforest along an altitudinal gradient in southeastern Brazil. Biota Neotr. 12, 123-145.

Jones, B.A., Grace, D., Kock, R., Alonso, S., Rushton, J., Said, M.Y., McKeever, D., Mutua, F., Young, J., McDermott, J., Pfeiffer, D.U., 2013. Zoonosis emergence linked to agricultural intensification and environmental change. Proc. National Acad. Sci. $110,8399-8404$

Jorge, M.L.S.P., Galetti, M., Ribeiro, M.C., Ferraz, K.M.P.M.B., 2013. Mammal defaunation as surrogate of trophic cascades in a biodiversity hotspot. Biol. Conserv. 163, 49-57.

Keesing, F., 1998. Impacts of ungunlates on the demography and diversity of small mammals in central Kenya. Oecologia 116, 381-389.

Keesing, F., 2000. Cryptic consumers and the ecology of an African savanna. Bioscience 50, 205-215.
Keuroghlian, A., Desbiez, A.L.J., de Mello Beisiegel, B., Medici, E.P., Gatti, A., Pontes, A.R.M., de Campos, C.B., de Tófoli, C.F., Jr., E.A.M., de Azevedo, F.C., 2012. Avaliação do risco de extinção do queixada Tayassu pecari Link, 1795, no Brasil. Biodiversidade Brasileira, pp. 84-102.

Kiltie, R.A., Terborgh, J., 1983. Observations on the Behavior of Rain-Forest Peccaries in Peru - Why Do White-Lipped Peccaries Form Herds. Zeitschrift Fur Tierpsychologie-Journal of Comparative Ethology 62, 241-255.

Maclean, J.E., Goheen, J.R., Doak, D.F., Palmer, T.M., Young, T.P., 2011. Cryptic herbivores mediate the strength and form of ungulate impacts on a long-lived savanna tree. Ecology 92, 1626-1636.

McCauley, D.J., Keesing, F., Young, T.P., Allan, B.F., Pringle, R.M., 2006. Indirect effects of large herbivores on snakes in an African savanna. Ecology 87, 2657-2663.

Munger, J.C., Brown, J.H., 1981. Competition in desert rodents: an experiment with semipermeable exclosures. Science 211, 510-512.

Newsome, S.D., del Rio, C.M., Bearhop, S., Phillips, D.L., 2007. A niche for isotopic ecology. Front. Ecol. Environ. 5, 429-436.

Newsome, S.D., Yeakel, J.D., Wheatley, P.V., Tinker, M.T., 2012. Tools for quantifying isotopic niche space and dietary variation at the individual and population level. J. Mammal. 93, 329-341.

Norris, D., Rocha-Mendes, F., de Barros Ferraz, S.F., Villani, J.P., Galetti, M., 2011. How to not inflate population estimates? Spatial density distribution of whitelipped peccaries in a continuous Atlantic forest. Anim. Conserv. 14, 492-501.

Paise, G., 2010. Efeitos da fragmentação de habitat sobre a comunidade de pequenos mamíferos de Mata Atlântica no Estado de São Paulo. Universidade Estadual de Campinas, UNICAMP.

Palmer, T.M., Stanton, M.L., Young, T.P., Goheen, J.R., Pringle, R.M., Karban, R., 2008. Breakdown of an ant-plant mutualism follows the loss of large herbivores from an African savanna. Science 319, 192-195.

Parnell, A.C., Phillips, D.L., Bearhop, S., Semmens, B.X., Ward, E.J., Moore, J.W., Jackson, A.L., Grey, J., Kelly, D.J., Inger, R., 2013. Bayesian stable isotope mixing models. Environmetrics n/a-n/a. http://dx.doi.org/10.1002/env.2221.

Parsons, E.W., Maron, J.L., Martin, T.E., 2013. Elk herbivory alters small mammal assemblages in high elevation drainages. J. Anim. Ecol. 82, 459-467.

Peres, C.A., 1996. Population status of white-lipped Tayassu pecari and collared peccaries T. tajacu in hunted and unhunted Amazonian forests. Biol. Conserv. 77, 115-123.

Peres, C.A., Palacios, E., 2007. Basin-wide effects of game harvest on vertebrate population densities in amazonian forests: implications for animal-mediated seed dispersal. Biotropica 39, 304-315.

Phillips, D.L., 2001. Mixing models in analyses of diet using multiple stable isotopes: a critique. Oecologia 127, 166-170. http://dx.doi.org/10.1007/s004420000571.

Phillips, D.L., Inger, R., Bearhop, S., Jackson, A.L., Moore, J.W., Parnell, A.C., Semmens, B.X., Ward, E.J., 2014. Best practices for use of stable isotope mixing models in food web studies. Can. J. Zool. http://dx.doi.org/10.1139/cjz-2014-0127, 140827143520002 .

Pringle, R.M., 2008. Elephants as agents of habitat creation for small vertebrates at the patch scale. Ecology 89, 26-33.

R Development Core Team, 2014. R: A Language and Environment for Statistical Computing. Vienna, Austria.

Reider, K.E., Carson, W.P., Donnelly, M.A., 2013. Effects of collared peccary (Pecan tajacu) exclusion on leaf litter amphibians and reptiles in a Neotropical wet forest, Costa Rica. Biol. Conserv. 163, 90-98.

Ripple, W.J., Estes, J.A., Beschta, R.L., Wilmers, C.C., Ritchie, E.G., Hebblewhite, M., Berger, J., Elmhagen, B., Letnic, M., Nelson, M.P., Schmitz, O.J., Smith, D.W., Wallach, A.D., Wirsing, A.J., 2014. Status and ecological effects of the world's largest carnivores. Science 343.

Rocha-Mendes, F., Neves, C.L., Nobre, R.d.A., Marques, R.M., Bianconi, G.V., Galetti, M., 2015. Non-volant mammals from Núcleo Santa Virgínia, Serra do Mar State Park, São Paulo, Brazil. Biota Neotropica 15, 1-9.

Silman, M.R., Terborgh, J.W., Kiltie, R.A., 2003. Population regulation of a dominantrain forest tree by a major seed-predator. Ecology 84, 431-438.

Suzán, G., Marcé, E., Giermakowski, J.T., Mills, J.N., Ceballos, G., Ostfeld, R.S., Armién, B., Pascale, J.M., Yates, T.L., 2009. Experimental evidence for reduced rodent diversity causing increased hantavirus prevalence. Plos One 4, e5461.

Suzuki, A., Bisordi, I., Levis, S., Garcia, J., Pereira, L.E., Souza, R.P., Sugahara, T.K., Pini, N., Enria, D., Souza, L.T., 2004. Identifying rodent hantavirus reservoirs, Brazil. Emerg. Infectious Diseases 10, 2127-2134.

Wright, S.J., 2003. The myriad consequences of hunting for vertebrates and plants in tropical forests. Perspect. Plant Ecol. Evol. Syst. 6, 73-86. 